\title{
The Absurdity of the Absurd: The Meta Narrative of Nothingness
}

\author{
Dr Disha Madan \\ PG Department of Studies in English \\ Nehru College \& PG Centre, Hubli \\ dishamadanssdm@gmail.com
}

\begin{abstract}
The Theatre of the Absurd focuses on the absurdity and uncertainty of life and time. Visual images that we actually see and what appears in dreams and memories and the non verbal consciousness of pure emotion are vital constituents of our awareness of ourselves. Yet, this awareness has to turn into consciousness of the unconscious. And, in this process the Self is a mystery - ever elusive exemplified by the impermanence of the human personality in time. The only authentic experience that can be communicated is the experience of the single moment in the fullness of its emotional intensity, its existential totality. This paper focuses on the fleeting vignettes of the Self and the Self finds integrity in Nothingness. The theatre of the Absurd finds a meaning in Nothingness beyond words and language. The ever elusive words still speak of a sense which lies in unconsciousness. The consciousness of the unconscious provides eternal integrity to the body, mind and the soul.
\end{abstract}

Keywords: Absurd, metaphysical, transcendental roots, waiting, time, nothingness, search for reality, colonial frenzy, inward eye.

\section{INTRODUCTION}

On November 1957, a group of worried actors were preparing to face their audience. The actors were the members of the company of San Francisco Actors' workshop. The audience consisted of fourteen hundred convicts at Quentin penitentiary. The play chosen for the occasion was Samuel Beckett's Waiting for Godot. It was a highly obscure and intellectual play. Herbert Blau, the director was apprehensive. He stepped on to the stage and prepared the audience of convicts. He compared the play to a piece of jazz music "to which one must listen for whatever one may find in it." 1 In the same way he hoped, there would be some meaning, some personal significance for each member of the audience in Waiting for Godot.

The curtain parted, the play was staged. And, what had bewildered the sophisticated audiences of Paris, London, and New York was immediately grasped by an audience of convicts. The play left a deep impact on the audience. A reporter from the San Francisco Chronicle who was present noted that the convicts did not find it difficult to understand the play. One prisoner told him

"Godot is society." Said another: "He's the outside." 2 The play mesmerized the audience as it confronted them with a situation in some ways analogous to their own.

\section{A New Convention}

The reception of Waiting for Godot at San Quentin, and the wide acclaim given to plays by Eugene Ionesco, Arthur Adamov, Harold Pinter, and others, testify that these plays, which are often dismissed as nonsense or mystification, have something to say. A good play has to have a fully explained theme, which is neatly exposed and finally solved. But, these plays often do not have a beginning or an end. A good play is to hold the mirror up to nature and portray the manners and mannerisms of the age in finely observed sketches. But, these plays seem to be the reflections of dreams and nightmares. A good play depends on witty repartee and dialogue. But, these often consist of incoherent babblings.

In one of the great seminal heart-searchings of our time, The Myth of Sisyphus, Albert Camus tried to diagnose the human situation in a world of shattered beliefs. Thus, "....But in a universe, that is suddenly deprived of illusions and of light, man feels a stranger. He is in irremediable exile....This divorce between man and his life, the actor and his setting, truly constitutes the feeling of Absurdity."3 


\section{Dr Disha Madan}

'Absurd' originally means 'out of harmony', in a musical context. Hence, its dictionary definition: 'out of harmony with reason or propriety; incongruous, unreasonable, illogical.' In common usage, 'absurd' may simply mean 'ridiculous', but this is not the sense in which Camus uses this word, and in which it is used when we speak of the Theatre of the Absurd. In an essay on Kafka, Ionesco defined it so, "Absurd is that which is devoid of purpose....Cut off from his religious, metaphysical, and transcendental roots, man is lost; all his actions become senseless, absurd, and useless."4

The Theatre of the Absurd strives to express the sense of metaphysical anguish at the absurdity of the human condition, but abandons the rational devices and discursive thought in doing so. It tries to achieve a unity between its basic assumptions and the forms in which they are expressed. It is an inner contradiction that the dramatists of the Absurd are trying, by instinct and intuition rather than by conscious effort to overcome and resolve. They do not argue about the absurdity of human condition but merely present it in being-that is, in terms of concrete stage images. It highlights the difference between theory and experience. It is this striving for integration between the subject-matter and the form in which it is expressed that separates the Theatre of the Absurd from Existentialist theatre. It is broadly based on ancient strands of the Western tradition and has its exponents in Britain, Spain, Italy, Germany, Switzerland, Eastern Europe, United States and France. It has produced the framework of values with bewildering results bringing in a new and revolutionary convention.

\section{WAITING FOR GODOT: SEARCH FOR THE SELF IN NOTHINGNESS}

Waiting for Godot does not tell a story, it explores a static situation. "Nothing happens, nobody comes, nobody goes, and it's awful."5 On a country road, by a tree, two old tramps, Vladamir and Estragon, are waiting for Godot. When Alan Schneider, who was to direct the first American production of Waiting for Godot, asked Beckett who or what was meant by Godot, he received the answer, "If I knew, I would have said so in the play."6 Yet, whether Godot is meant to suggest the intervention of supernatural agency or whether he stands for a mythical human being whose arrival is expected to change the situation, or both of these possibilities combined, his exact nature is of secondary importance.

The subject of the play is not Godot but waiting, the act of waiting as an essential and characteristic aspect of the human condition. Throughout our lives we always wait for something - an event, a thing, a person, death. Moreover, it is an act of waiting that we experience the flow of time in its purest, most evident form. If we are active, we tend to forget the passage of time, we pass the time, but if we are merely passively waiting, we are confronted with the action of time itself. As Beckett points out in his analysis of his play Proust, "There is no escape from the hours and the days....Yesterday is not a milestone that has been passed, but a daystone on the beaten track of years, and immediately part of us, within us, heavy and dangerous. We are not merely wearier because of yesterday; we are other, no longer what we were before the calamity of yesterday."7

The flow of time confronts us with the basic problem of being- the problem of the nature of the self. This self is subject to constant change in time, which is in constant flux and therefore always outside our grasp. At no single moment in our lives we can be identical with ourselves.

Waiting is to experience the action of time, which is constant change. And yet, as nothing real ever happens, that change is in itself an illusion. The ceaseless activity of time is self-defeating, purposeless, and therefore null and void. The more things change, the more they are the same. That is the terrible stability of the world. One day is like another, and when we die, we might never have existed.

In one of Beckett's favourite quotations, "Nothing is more real than nothing." 8 Time does not cease or pause, but positive peace comes in when one gives way to passing thoughts and simply adding on things to the Nothing. This Nothing can be One-and- Only or the union with nothingness in the form of death. Wherein, the disintegrating self finds its way back to integration. The material wants and desires, as they are pursued and attained, they recede. The action of time changes us in the process of reaching what we crave. It finally finds release only in the recognition of that nothingness which is the only reality. All other movement is disorder. Everything else is futile.

All external recognitions and the suppressions, animal, human or divine are stored in a human being. The flight from these perceptions in an attempt to reach the positive nothingness of non -being is a significant part of the Absurd. For, the true release lies in ones knowing that one is no longer conscious. Yet, with death, consciousness comes to a halt and the last moment of a dying man's consciousness can be imagined as an eternal awareness of unconsciousness. 
Beckett opines, "I am interested in the shape of the ideas even if I do not believe in them....That sentence has a wonderful shape. It is the shape that matters."9 It is the shape of the ideas that fascinated Beckett. Out of all the malefactors, out of all the millions and millions of criminals that have been executed in the course of history, two, only two, had the chance of receiving absolution in the hour of their death in so uniquely effective a manner. One happened to make a hostile remark; he was damned. One happened to contradict that hostile remark; he was saved. How easily could the roles have been reversed? These, after all, were not well considered judgements, but chance exclamations uttered at a moment of supreme suffering and stress. As Pozzo says about Lucky, "Remark that I might easily have been in his shoes and he in mine. If chance had not willed it otherwise. To each one his due."10 And, then our shoes might fit us one day and not the next. Estragon's boots torment him in the first act and in act two they fit him miraculously.

\section{VACUITY OF THE LANGUAGE}

To be alive is to be aware of oneself and to hear one's thoughts and endless stream of words. As a human being, we all bear this compulsion. Samuel Beckett rejects language and simultaneously, as a poet, he is also compelled to work with language. This is a paradox, that language appears to him as a divine instrument and, at times, it is a mere senseless buzzing. Sometimes, he articulates language equating it with the inarticulate sounds of nature. In a world that has lost its meaning, language also becomes a meaningless buzzing. In a meaningless universe, a positive statement cannot be made.

Simple misunderstandings, and double monologues, clichés, repetition of synonyms, inability to find the right words and chaotic use of words, dropping of punctuation marks - all indicates that language has lost its function as a means of communication and that questions have turned into statements which do not require an answer.

If Beckett's plays are concerned with expressing the difficulty of finding the meaning in a world subject to incessant change, his use of language probes the limitations of language both as a means of communication and as the vehicle for expression of valid statements, an instrument of thought. In a purposeless world that has lost its ultimate objectives, dialogue, like all action, becomes a mere game to pass the time. He attempts to reduce the gap between the limitation of language and the intuition of being. Words fall short in expressing the deepest thoughts in man. Language serves to express the breakdown, the disintegration of thought and life. Where there is no certainty, there can be no definite meaning. And, the impossibility of ever attaining certainty is one of the main themes of the theatre of the Absurd Theatre.

Through its constant stress on the uncertainty of the appointment with Godot, Godot's unreliability and irrationality, and the repeated demonstration of the futility of the hopes pinned on him, the act of waiting for Godot is shown as essentially absurd. All the activities in the play are aspects of the futile preoccupation with objectives and illusory goals. All movement is disorder. The hope of salvation may be merely an evasion of the suffering and anguish that spring from facing the reality of the human condition. Beckett's creative intuition explores the elements of experience and shows to what extent all human beings carry the seeds of such depression and disintegration within the deeper layers of their personality. If the prisoners of San Quentin responded to Waiting for Godot, it was because they were confronted with their own experience of time, waiting, hoping, and despair; because they recognized the truth about their own human relationships.

This is also the key to the wide success of Beckett's plays: to be confronted with concrete projections of the deepest fears and anxieties, which have been only vaguely experienced at a half-conscious level, constitutes the process of catharsis and liberation analogous to the therapeutic effect in psychoanalysis of confronting the subconscious contents of the mind. This is the moment of release from deadening habit, through facing up to the suffering of existence. The Absurd Theatre can be seen as a search for reality that lies behind mere reasoning in conceptual terms. Language is devalued as an instrument for the communication of ultimate truths, but these writers are great masters of language as an artistic medium.

\section{Conclusion}

This acceptance of the world, as it is, and rejection of its language, principles and realities makes the Theatre of the Absurd reverberates with another possibility. It can also be termed as the rejection of the inner colonial frenzy. The meaninglessness of one's identity and existence also crops up from the 
sameness of the universe. The question of being or not being stands forth as all actions lead to nothingness. The reality lies not in visual perceptions but in sensing the depth of realities in nothingness. The unconscious senses lie unperturbed in the inner assess of the self and the space. This hunt for the reality is not in pursuing action, but, in being unconscious of oneself and one's thoughts. In the vacuum of silence lies the music of the self and the-Only-Nothing. An attempt to communicate the incommunicable is the recognition of the illusoriness and absurdity of the readymade solutions to life and its problems. The realization of the questions is in itself the starting point of a new kind of consciousness. Such consciousness cannot end in despair, but appears to be more powerful to face the mysteries of life.

The ultimate truths cannot be lined out in black and white, as certain traumas can never be specified. Various kinds of fears and phobias rule the human mind. The human mind cannot evade such terrors. The mystery of the self is ever elusive and the material word requires verbal expression. The usage of language shows the impact of influence on the individual. In other words, the language is also a sign of colonization. Hence, the decolonization of the body, mind and the soul with the language and culture removes the film of unreality. The bare touch of unconscious with consciousness makes one dance with the Inward Eye of Nothingness.

\section{REFERENCES}

[1] Esslin, Martin. The Theatre of the Absurd. New York: Bloomsbury. Rpt 2014. Introduction. p 1.

[2] Theatre Arts. New York, July 1958.

[3] Camus, Albert. Le Mythe de Sisyphe. Paris: Gallimand, 1942. p. 18.

[4] Ionesco, Eugene, 'Dans les armes de la ville', Cahiers se la Compagnie Madeleine RenaudJean-Louis Barrault, Paris, no.20, October 1957.

[5] Beckett, Samuel. Waiting for Godot. London: Faber \& Faber, 1959, p.41.

[6] Schneider, Alan. Waiting for Beckett, Chelsea Review, New York, Autumn 1958.

[7] Beckett, Samuel. Proust. New York: Grove Press, no date, pp. 2-3.

[8] Beckett, Samuel. Malone Dies, in Molloy/Malone Dies/The Unnamable. London: John Calder,1959, p. 193.

[9] Beckett, quoted by Harold Hobson, op.cit., and by Alan Schneider, op.cit.

[10] Beckett, Samuel. Waiting for Godot. London: Faber \& Faber, 1959, p.31.

\section{AUTHOR's BIOGRAPHY}

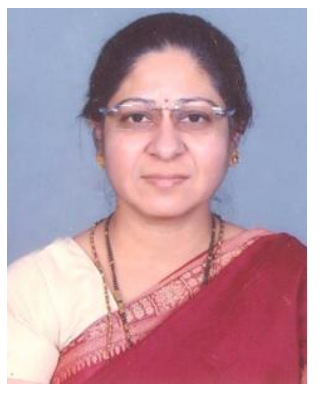

Dr.Disha Madan, is working as Lecturer in the PG Department of Studies in English, Nehru College and PG Center, Hubli (Karnataka). She is having vast experience of teaching at $\mathrm{UG}$ and $\mathrm{PG}$ level.

She has published research articles in reputed International journals and coauthor of a book 'The Double Bind: Women of Color (African American Women Writers)'; and written epilogue for the translated poems 'My Fifty-One Poems' translated from Hindi poems of Atalbihari Vajpayee, former Prime Minister of India.

She has presented papers at National and International Conferences and chaired the sessions. She was also a resource person for one of the conferences.

She is associated with a research project of Massey University, New Zealand, 2015 Pro-Bono.

She is the President of International Inner Wheel Club of Hubli Town Dist. 317 for the year 2015-16. 